\title{
Distinct Patterns of Neuropeptide Gene Expression in the Lateral Hypothalamic Area and Arcuate Nucleus Are Associated with Dehydration-Induced Anorexia
}

\author{
Alan G. Watts, Graciela Sanchez-Watts, and Andrea B. Kelly \\ The Neuroscience Program and the Department of Biological Sciences, University of Southern California, \\ Los Angeles, California 90089-2520
}

\begin{abstract}
We have investigated the hormonal and hypothalamic neuropeptidergic substrates of dehydration-associated anorexia. In situ hybridization and hormone analyses of anorexic and paired food-restricted rats revealed two distinct profiles. First, both groups had the characteristic gene expression and endocrine signatures usually associated with starvation: increased neuropeptide $Y$ and decreased proopiomelanocortin and neurotensin mRNAs in the arcuate nucleus (ARH); increased circulating glucocorticoid but reduced leptin and insulin. Dehydrated animals are strongly anorexic despite these attributes, showing that the output of leptin- and insulin-sensitive ARH neurons that ordinarily stimulate eating must be inhibited. The second pattern occurred only in anorexic animals and had two components: (1) reduced corticotropin-releasing hormone $(\mathrm{CRH})$ mRNA in the neuroendocrine paraventricular nucleus (PVH) and (2) increased $\mathrm{CRH}$ and neurotensin mRNAs in the lateral hypothalamic (LHA) and retrochiasmatic areas. However, neither corticosterone nor suppressed $\mathrm{PVH}$ CRH gene expression is
\end{abstract}

required for anorexia after dehydration because $\mathrm{PVH} \mathrm{CRH}$ mRNA in dehydrated adrenalectomized animals is unchanged from euhydrated adrenalectomized controls. We also showed that LHA CRH mRNA was strongly correlated with the intensity of anorexia, increased LHA CRH gene expression preceded the onset of anorexia, and dehydrated adrenalectomized animals (which also develop anorexia) had elevated LHA CRH gene expression with a distribution pattern similar to intact animals. Finally, we identified specific efferents from the $\mathrm{CRH}$-containing region of the LHA to the $\mathrm{PVH}$, thereby providing a neuroanatomical framework for the integration by the $\mathrm{PVH}$ of neuropeptidergic signals from the ARH and the LHA. Together, these observations suggest that $\mathrm{CRH}$ and neurotensin neurons in the LHA constitute a novel anatomical substrate for their well known anorexic effects.

Key words: feeding behavior; anorexia; neuropeptides; corticotropin-releasing hormone; arcuate nucleus; lateral hypothalamus; paraventricular nucleus; leptin; glucocorticoid
Feeding in rats is regulated, like other motivated behaviors, by interactive inhibitory and stimulatory networks (Stricker, 1990). Rat ingestive behaviors consistently and predictably occur during the dark period with unlimited food and water. Eating and drinking are alternately initiated and terminated by integrative mechanisms involving peptidergic neural circuits, visceral sensory feedback, and circulating nutrient and hormone levels (Woods et al., 1998). Dysfunction in this physiological network disturbs eating behaviors with serious consequences. For example, disruption of leptin and associated neuropeptide signaling results in obesity (Elmquist et al., 1999), whereas an inability to restrain inhibitory mechanisms leads to anorexia, with consequent negative energy balance and body wasting (Schwartz et al., 1995).

Several neuropeptides are strongly implicated in activating eating, and the detailed organization of their cognate neural circuits is being clarified. For example, to regulate eating, leptin targets neuropeptide-containing neurons in a primary network consisting of the arcuate $(\mathrm{ARH})$, ventromedial $(\mathrm{VMH})$, dorso-

\footnotetext{
Received Feb. 25, 1999; revised April 27, 1999; accepted April 27, 1999.

This study was supported by Grant NS 29728 (A.G.W.) from the National Institute of Neurological Diseases and Stroke, National Institutes of Health. We thank Drs. P. Dobner (NT/N), D. Larhammar (NPY), J. Majzoub (CRH), and J. Roberts (POMC) for gifts of cDNAs for probe preparation. We also thank Cynthia KayNishiyama and Dr. JunQi Zheng for technical assistance.

Correspondence should be addressed to Dr. Alan G. Watts, Program in Neural, Informational and Behavioral Sciences, Hedco Neuroscience Building, MC 2520, University of Southern California, Los Angeles, CA 90089-2520.

Copyright (C) 1999 Society for Neuroscience $0270-6474 / 99 / 196111-11 \$ 05.00 / 0$
}

medial $(\mathrm{DMH})$ nuclei, and retrochiasmatic area $(\mathrm{RCH})$, with further contributions from the lateral hypothalamic area (LHA) and paraventricular nucleus (PVH) (Elmquist et al., 1998a,c). In this context, neuropeptide Y (NPY) stimulates food intake when injected into the brain, whereas altered NPY and proopiomelanocortin (POMC) mRNA levels in the ARH occur during deprivation (for review, see Woods et al., 1998). Regarding behavioral inhibition, deprivation-induced eating is suppressed by intraventricular injection of corticotropin-releasing hormone $(\mathrm{CRH})$ or neurotensin (Morley, 1987; Woods et al., 1998). Agonists of the melanocortin (MC) 3/4 receptor reduce food intake (Fan et al., 1997; Thiele et al., 1998), whereas MC3/4R antagonist administration or MC4R knockout mice provoke hyperphagia (Hruby et al., 1995; Huszar et al., 1997). Although the PVH is implicated in mediating some of these anorectic effects (Heinrichs et al., 1993), the details of the circuits responsible for generating anorexia remain less clearly defined than those responsible for stimulating eating.

To examine this question we have used in situ hybridization to compare the dynamics of four key neuropeptide mRNAs (CRH, neurotensin, NPY, POMC) in the ARH, PVH, LHA, and RCH during dehydration-associated anorexia and pair-fed food deprivation. Although thirst is the obvious behavioral correlate of dehydration, when prolonged it also generates an intense anorexia (Watts, 1999). Because digestion requires significant water investment, some of which is subsequently lost by colonic excretion, dehydration-associated anorexia is a physiologically gener- 
ated behavioral reflex critical for protecting the fluid compartment. We have recently shown that when animals are dehydrated by replacing drinking water with $2.5 \%$ saline, anorexia develops relatively slowly but is rapidly reversed once access to water is restored, a behavioral structure consistent with the presence of simultaneous activated sets of neural circuits that independently stimulate or suppress eating (Watts, 1999). We hypothesize that modified patterns of appetite-regulating neuropeptide gene expression apparent during dehydration but not food restriction are associated with anorexia, whereas changes seen during both dehydration and food restriction are likely associated with hunger and the ensuing bout of eating that occurs once water is returned (Watts, 1999). Because these data identified the LHA as a potential mediator of anorexia, we also used injections of Phaseolus vulgaris leucoagglutinin (PHA-L) to determine whether the region containing $\mathrm{CRH}$ neurons provides afferent projections to the $\mathrm{PVH}$.

Some of these data have been reported previously in abstract form (Watts and Sanchez-Watts, 1998; Watts et al., 1998)

\section{MATERIALS AND METHODS}

Animals. Adult male Sprague Dawley rats [250-260 gm body weight (BW) at the start of the experiment] were individually caged and maintained on a $12 \mathrm{hr}$ light/dark schedule with lights on at 6 A.M. with unlimited access to food (Teklad rodent diet 8604) and water. Food intake and body weights of all animals were measured twice daily at 8-9 A.M. and 5-6 P.M. throughout the experiment. Intact animals were selected to begin the control, food restriction (FR), or dehydration (DE) schedules when their body weights were $\sim 300 \mathrm{gm}$. At this time there were no significant differences in body weights among the three groups. For experiments involving adrenalectomized (ADX) animals, adrenals were removed through bilateral flank incisions under halothane anesthesia, and in addition to rodent diet, animals were offered water and $0.9 \%$ saline. ADX animals began the dehydration regimen only when all animals had showed increases in body weight for at least 5 consecutive days.

Control, dehydration, and food restriction regimens. Control euhydrated (EU) animals continued throughout the experiment with unlimited access to water and food, whereas the water supply of all DE animals (intact and $\mathrm{ADX}$ ) was replaced with $2.5 \%$ saline at noon on day 0 and continued for $5 \mathrm{~d}$. The FR schedule was maintained for $5 \mathrm{~d}$ in a third group of intact animals that were offered water rather than hypertonic saline. The FR schedule was designed so that animals were pair-fed the same amount of food during each $12 \mathrm{hr}$ light and dark period as was eaten by intact-DE animals. The amount of food provided for each period was determined from previously published data on intact-DE animals (Watts, 1999) and was calculated individually as a percentage per $100 \mathrm{gm} \mathrm{BW}$ of mean body weight during the $3 \mathrm{~d}$ preceding the start of the restriction schedule. Food for each animal was provided every day until they were killed after measurements were taken at 8-9 A.M. and 5-6 P.M.

Sample collection. Animals were killed by one of two methods at noon on day 5. First, animals destined for in situ hybridization were decapitated, and their brains were rapidly removed and immediately placed in ice-cold $4 \%$ paraformaldehyde in $0.01 \mathrm{~m}$ borate buffer, $\mathrm{pH} 9.5$, for $24 \mathrm{hr}$. Fresh fixative containing $12-15 \%$ sucrose was added after $24 \mathrm{hr}$, and brains were fixed for a further $24 \mathrm{hr}$ at $4-6^{\circ} \mathrm{C}$. We have reported previously that fixing brain tissue in this manner is entirely compatible with quantitative in situ hybridization (Tanimura and Watts, 1998). All brains were then frozen on powdered dry ice and stored at $-70^{\circ} \mathrm{C}$ until sectioning for in situ hybridization at a later date. Trunk blood from these same animals was collected at decapitation into three cooled plastic tubes: one for serum preparation (for leptin assay), one coated with 0.01 M EDTA (for ACTH assay), and one coated with heparin (for insulin and corticosterone assays). After a small sample was removed for hematocrit determination, all blood samples were centrifuged, and plasma was removed, aliquoted, and stored at $-40^{\circ} \mathrm{C}$ until assayed for plasma osmolality and plasma hormone determinations at a later date. In the second method, animals destined for immunocytochemistry were anesthetized with tribromoethanol and perfused as described previously (Kelly and Watts, 1998). After perfusion, brains were removed from the skull and post-fixed for $24 \mathrm{hr}$ in $\mathrm{pH} 9.54 \%$ paraformaldehyde $/ 0.01 \mathrm{M}$ borate fixative, and brains were frozen on dry ice and stored as just described.
Radioimmunoassays. Concentrations of serum leptin, plasma ACTH, insulin, and corticosterone were all measured by double-antibody radioimmunoassays (RIAs) using commercially available ${ }^{125}$ I-labeled antigen kits. Plasma insulin and leptin were measured using kits purchased from Linco Research (St. Charles, MI), with the lower sensitivity limits being $100 \mathrm{pg} / \mathrm{ml}$ and $0.5 \mathrm{ng} / \mathrm{ml}$, respectively, whereas the intra-assay coefficients of variation were $<9.4 \%$ and $<6.8 \%$, respectively. Plasma ACTH concentrations were determined using an RIA kit purchased from ICN Biochemicals (Costa Mesa, CA). The lower sensitivity limit was $30 \mathrm{pg} / \mathrm{ml}$, and the intra-assay coefficient of variation was $<10.5 \%$. Plasma corticosterone concentrations were determined using an RIA kit purchased from ICN Biochemicals. The lower sensitivity limit was $12 \mathrm{ng} / \mathrm{ml}$, and the intra-assay coefficient of variation was $<8.5 \%$. For all hormones, all samples were run in single assays.

In situ hybridization. Eight series of one in eight 15 - $\mu \mathrm{m}$-thick frontal sections were cut through the hypothalamus and saved in ice-cold potassium PBS (KPBS) containing $0.25 \%$ paraformaldehyde, $\mathrm{pH}$ 7.4. Sections were mounted the same day onto poly-L-lysine-coated gelatin-subbed slides, vacuum-desiccated overnight, post-fixed in KPBS/4\% paraformaldehyde for $1 \mathrm{hr}$ at room temperature, rinsed five times for $5 \mathrm{~min}$ in clean $\mathrm{KPBS}$, air-dried, and then stored at $-70^{\circ} \mathrm{C}$ in air-tight containers containing silica-gel desiccant for hybridization at a later date. Serial sections were saved for thionin staining.

Sections were hybridized using ${ }^{35}$ S-labeled cRNA probes for ppCRH [a $700 \mathrm{bp}$ fragment encoding part of exon 1 and all of exon 2 (Frim et al., 1990)], ppNT/N [a 336 bp fragment encoding part of exon 4 (Kislauskis and Dobner, 1990)], POMC [a 538 bp fragment encoding part of exon 3 (Drouin and Goodman, 1980)], or N PY [a 287 bp fragment encoding part of exon 2 (Larhammar et al., 1987)] mRNAs synthesized as described previously (Watts and Sanchez-Watts, 1995b). Briefly, sections were prehybridized, hybridized for $20-22 \mathrm{hr}$ at $60^{\circ} \mathrm{C}$ using a probe concentration of $5 \times 10^{6}$ or $10^{7} \mathrm{cpm} / \mathrm{ml}$ of hybridization buffer, followed by posthybridization with RNase treatment at $37^{\circ} \mathrm{C}$ and room temperature washes of from $4 \times$ to $0.1 \times \mathrm{SSC}$ at $65^{\circ} \mathrm{C}$, and dehydrated in alcohols. Sections were exposed to Microvision-C x-ray film (Sterling Diagnostic Imaging, Newark, DE) for varying periods (2-8 d), dipped in nuclear track emulsion (Kodak NTB-2; diluted 1:1 with distilled water), and then exposed for 5-21 d, developed, and counterstained with thionin.

In situ hybridization data analysis. Relative levels of mRNA were measured in anatomically defined regions on Microvision-C X-ray film exposures using a SC501 CCD camera (VSP Laboratories, Ann Arbor MI) connected through a Perceptics Pixel Buffer frame grabber and IPLab Spectrum software (v2.51; Signal Analytics Corp., Vienna, VA) to a Macintosh IIfx computer, as described elsewhere (Watts and SanchezWatts, 1995a,b; Watts et al., 1995).

The area on the film image corresponding to each anatomical region chosen for analysis was determined with careful reference to local cytoarchitectonics on the adjacent thionin-stained sections and the corresponding dipped autoradiographs. The area of the LHA used for analyzing CRH and NT/N mRNA [LHA-crh (Kelly and Watts, 1998)] was determined using previously published maps for reference (Kelly and Watts, 1998). Specifically, this area was contained within the five consecutive one in eight sections starting at the most caudal aspect of the PVH [level 27 of Swanson (1992)]. The delineated region extended from the fornix medially to the internal capsule laterally, and the zona incerta dorsally to the ventral surface of the brain. CRH mRNA-containing cells considered to be supraoptic magnocellular neurons located on the most ventral aspect of the hypothalamus were excluded. CRH or NT/N mRNA levels in the $\mathrm{RCH}$ were measured from signal in the four consecutive one in eight sections beginning with the section closest to level 25 of Swanson (1992). For POMC, NPY, and NT/N mRNA levels in the ARH, signal for each was measured in the eight consecutive one in eight sections beginning with the section closest to level 26 of Swanson (1992).

Two quantitative indices of mRNA levels were obtained. First, the mean gray level (MGL) of hybridization in CRH mRNA-containing cells in the anatomically defined dorsal aspect of the medial parvicellular PVH (PVHmpd) was determined as described previously (Watts and Sanchez-Watts, 1995b; Tanimura and Watts, 1998). This value is dependent on the amount of mRNA per cell (Watts et al., 1995). Second, to determine the effects of the treatments on neuropeptide mRNA levels in the LHA, RCH, and ARH we measured the total pixel area occupied on the film image by hybridization signal from labeled cells within these anatomically defined areas. In brief, the total pixel area of the image within the anatomically defined region was noted after image segmentation at a value corresponding to 3 SDs above the mean background value 


\begin{tabular}{|c|c|c|c|c|c|}
\hline & $\begin{array}{l}\text { Control- } \\
\text { euhydrated }\end{array}$ & Dehydrated & Food-restricted & $\begin{array}{l}\text { Adrenalectomy- } \\
\text { euhydrated }\end{array}$ & $\begin{array}{l}\text { Adrenalectomy- } \\
\text { dehydrated }\end{array}$ \\
\hline \multicolumn{6}{|l|}{ Body weight (gm) } \\
\hline Day 0 & $303.7 \pm 3.0$ & $298.1 \pm 3.6$ & $296.4 \pm 2.5$ & $290.6 \pm 9.1$ & $290.7 \pm 1.3$ \\
\hline Day 5 & $336.8 \pm 3.8$ & $245.0 \pm 5.1$ & $267.7 \pm 2.0$ & $311.3 \pm 5.8$ & $253.2 \pm 4.4$ \\
\hline \multicolumn{6}{|l|}{ Plasma osmolality $(\mathrm{mOsm} / \mathrm{kg}$ / } \\
\hline $\left.\mathrm{H}_{2} \mathrm{O}\right)$ & $292 \pm 2$ & $326 \pm 6^{* *}$ & $296 \pm 1$ & $289 \pm 1$ & $305 \pm 4^{\dagger}$ \\
\hline Hematocrit $(\%)$ & $46.8 \pm 1.1$ & $54.7 \pm 2.1^{*}$ & $48.6 \pm 1.6$ & $45.2 \pm 0.3$ & $49.0 \pm 1.7^{\dagger \dagger}$ \\
\hline Thymus weight (mg) & $555 \pm 41$ & $400 \pm 16^{*}$ & $357 \pm 22 *$ & $668 \pm 49^{* *}$ & $665 \pm 14^{* * *}$ \\
\hline Plasma ACTH (pg/ml) & $83.6 \pm 8.8$ & $113.0 \pm 16.9$ & $98.7 \pm 10.3$ & Not assayed & Not assayed \\
\hline Plasma corticosterone $(\mathrm{ng} / \mathrm{ml})$ & $6.3 \pm 2.7$ & $67.0 \pm 22.5^{*}$ & $85.7 \pm 13.5^{* *}$ & Not detected & Not detected \\
\hline Plasma insulin $(\mathrm{pg} / \mathrm{ml})$ & $807 \pm 113$ & $207 \pm 16^{* * *}$ & $185 \pm 16^{* * *}$ & $228 \pm 47$ & $143 \pm 48$ \\
\hline Serum leptin $(\mathrm{ng} / \mathrm{ml})$ & $2.6 \pm 0.7$ & Not detected & Not detected & Not detected & Not detected \\
\hline Animals per group & 4 & 6 & 6 & 4 & 4 \\
\hline
\end{tabular}

${ }^{*} p<0.01 ; * * p<0.0002 ; * * * p<0.0001$ versus euhydrated control.

${ }^{\dagger} p<0.05 ;{ }^{\dagger \dagger} p<0.002$ versus euhydrated adrenalectomy.

(determined from adjacent areas showing no specific labeling). We have reported previously that this method excludes $\geq 98 \%$ of background pixels (Watts et al., 1995). The derived value is dependent on the total number of mRNA-containing cells within the region of interest. For each mRNA in each region, the total pixel area used for subsequent analysis was derived by summing the area values from each of the sections in the series. In addition, because of the heterogenous pattern of CRH and $\mathrm{NT} / \mathrm{N}$ gene expression in the LHA-crh, both the MGL of the region of specific labeling and its total pixel area were determined on the appropriate segmented images.

Significance of differences between treatment groups was determined using single-factor ANOVA followed by Dunnett's post hoc test for comparison with control values or unpaired Students $t$ test, where appropriate.

Phaseolus vulgaris leucoagglutinin injections. A 2.5\% solution of PHAL in sodium PBS was iontophoresed within the LHA-crh of 18 DE animals through glass microelectrodes (inner tip diameter 10-15 $\mu \mathrm{m}$ ). A $5 \mu \mathrm{A}$ direct current ( $7 \mathrm{sec}$ on, $8.5 \mathrm{sec}$ off) was delivered by a high-voltage precision current source (model CS3, Transkinetics, Canton, MA) for up to 20 min (Kelly and Watts, 1998). Two weeks later animals were perfused, and brains were removed from the skull, post-fixed, frozen in powdered dry ice, and then stored at $-70^{\circ} \mathrm{C}$. Frozen coronal sections $(30$ $\mu \mathrm{m}$ ) were cut through the hypothalamus and collected into ice-cold $0.1 \mathrm{M}$ KPBS, $\mathrm{pH} \mathrm{7.4,} \mathrm{for} \mathrm{immediate} \mathrm{processing} \mathrm{or} \mathrm{into} \mathrm{buffered} \mathrm{glycerol/}$ sucrose cryoprotectant (Kelly and Watts, 1998) and stored at $-20^{\circ} \mathrm{C}$ for processing at a later date. Sections were rinsed three times for $5 \mathrm{~min}$ in KPBS immediately before incubation with primary antibody. Freefloating sections were incubated in anti-PHAL antibody (1:2000; Vector Labs, Burlingame, CA) containing $10 \%$ nonfat dry milk and $0.3 \%$ Triton $\mathrm{X}-100$ for $2-3 \mathrm{~d}$. Specific antibody staining was color-developed using a Vectastain Elite ABC kit (Vector Labs) followed by incubation in a 0.5 $\mathrm{mg} / \mathrm{ml}$ solution of diaminobenzidine (3,3 diaminobenzidine tetrahydrochloride) containing $0.1 \mu \mathrm{l} / \mathrm{ml}$ hydrogen peroxide. Sections were then rinsed, mounted on gelatin-coated slides, and vacuum-desiccated. Staining was amplified by incubation of the slides in $0.01 \% \mathrm{OsO}_{4}$, followed by a water rinse and dehydration through ascending concentrations of ethanol before being coverslipped with DPX mountant. The location of all the injections sites used in this study, as well as their relationship to CRH mRNA-containing neurons in DE animals, have been reported in detail in a previous publication from our laboratory (Kelly and Watts, 1998). The same experimental numbers have been retained here. The anatomical nomenclature of Swanson (1992) is used throughout.

\section{RESULTS}

\section{Effects of dehydration or pair-fed food restriction on body weight and food intake in intact and adrenalectomized animals}

On day 0 there was no significant difference in mean morning body weights between animals assigned to the EU, DE, or pairfed FR groups (Table 1). Although food intake was maintained

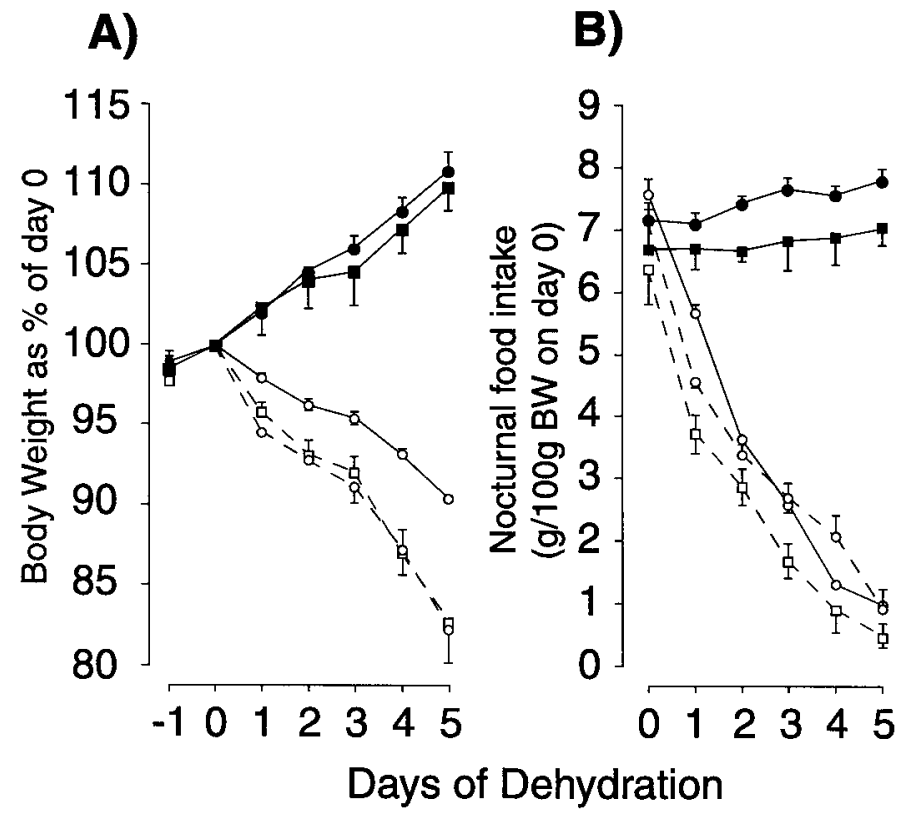

Figure 1. Changes in body weight and food intake during dehydration or food restriction. Mean $( \pm$ SEM) daily changes in body weight $(A)$ and nocturnal food intake $(B)$ of intact-EU (solid circles, solid lines), ADX-EU (solid squares, solid lines), intact-DE (open circles, dashed lines), ADX-DE (open squares, dashed lines), or intact-food restricted (open circles, solid lines) rats. Dehydration was started on day 0 by replacing drinking water with $2.5 \%$ saline.

and body weight progressively increased in EU animals, both variables declined during DE or FR (Fig. 1) with the reduction in food intake of the FR group being experimentally controlled. The rate of body weight loss during FR was significantly less than that seen in DE animals (Fig. 1 $A$ ), most likely because of a greater loss of body water from the latter group. As ADX-DE animals became progressively dehydrated, the rate of body weight reduction was no different from intact-DE animals (Fig. $1 A$ ). Figure $1 B$ shows the anticipated mild hypophagia of ADX-EU animals and that ADX-DE rats developed anorexia at rates indistinguishable from intact animals when related to body weight. 
Figure 2. Dehydration and food-restriction both affect arcuate nucleus gene expression. Mean $( \pm$ SEM) levels of NPY $(A)$, POMC $(B)$, and $\mathrm{NT} / \mathrm{N}(C)$ mRNA hybridization measured on treatment day 5 in the arcuate nucleus of euhydrated $(E U)$, dehydrated $(D E)$, and paired-food restricted $(F R)$ animals. ${ }^{*} p<0.01 ; * * p<0.001$; $*^{* * *} p<0.0002$ versus EU animals.
A)

B)

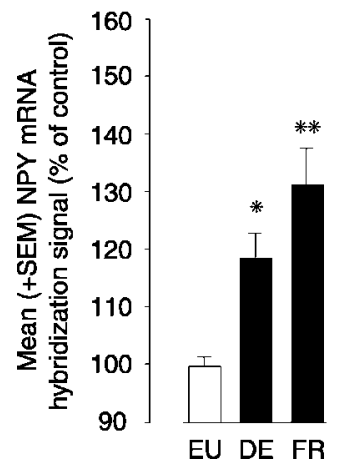

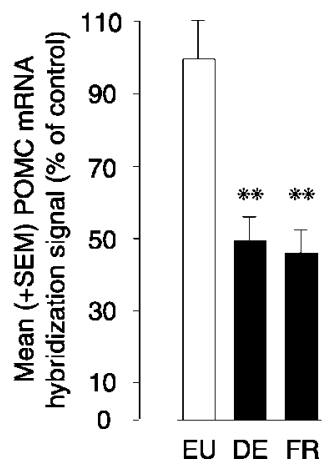

C)

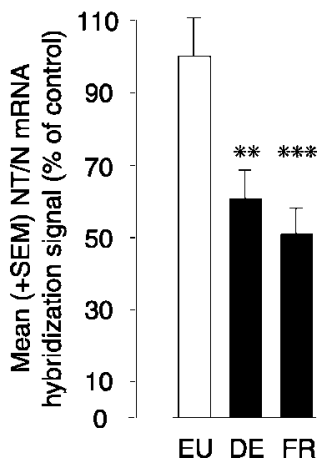

\section{Effects of dehydration or pair-fed food restriction on plasma osmolalities, hormone concentrations, and thymus weights in intact and adrenalectomized animals (Table 1)}

DE but not FR significantly increased plasma osmolality in intact animals. DE increased plasma osmolality in ADX animals, although this was not to the same extent as was observed in intact animals. Hematocrit was significantly increased only in intact-DE animals. DE and FR in intact animals had qualitatively similar effects on a number of other parameters. Thymus weights were equally and significantly lowered in intact-DE and FR animals compared with intact-EU animals. However, there was no significant difference between the thymus weights of ADX-EU and ADX-DE animals, and both values were significantly greater than intact-EU animals. Plasma ACTH concentrations were not significantly different between intact-EU, FR, and DE animals. However, plasma corticosterone concentrations were significantly elevated in intact-FR and intact-DE when compared with intact-EU animals. Plasma corticosterone was undetectable in all ADX animals. DE and FR significantly reduced plasma insulin concentrations in intact animals when compared with intact-EU animals, whereas serum leptin concentrations were reduced to undetectable levels by DE and FR. Serum leptin concentrations in ADX animals were undetectable in EU and DE. Plasma insulin concentrations were significantly lower in ADX-EU animals than in intact-EU animals and were not significantly affected by DE.

\section{Changes in neuropeptide gene expression observed during dehydration and pair-fed food restriction}

There are at least two possible mechanisms by which DE could conceivably act at the level of the ARH to generate anorexia: DE could reduce NPY levels (thereby reducing a major neural signal to eat), or it could increase ARH levels of anorexic neuropeptides, such as neurotensin or $\alpha$-MSH, or a combination of both. To test these possibilities, we compared the levels of NPY, POMC, and NT/N mRNAs in the ARH of pair-fed FR animals with those of DE-anorexic animals. The data shown in Figure 2 are clearly inconsistent with the hypothesis that DE targets the ARH to generate anorexia. Thus, DE and FR both modified levels of these mRNAs in the same direction. NPY was significantly increased in both instances (Fig. $2 A$ ), whereas DE and FR significantly decreased POMC (Fig. $2 B$ ) and NT/N (Figs. $2 C$, $3 B, D, F)$ mRNAs.

\section{Changes in neuropeptide gene expression observed only during dehydration}

Rather than an ARH-dependent mechanism, DE-associated anorexia could involve the specific activation of anorexigenic circuits. In this instance, we might expect to see divergent responses of anorexigenic neuropeptide mRNAs after DE and FR, with increased gene expression after DE but not FR. Based on previously published patterns of anorexigenic gene expression (Watts, 1992; Watts et al., 1995; Kelly and Watts, 1998), CRH and neurotensin in the LHA and $\mathrm{RCH}$, or $\mathrm{CRH}$ in the neuroendocrine $\mathrm{PVH}$, are candidate systems that could generate DEassociated anorexia. In this experiment we focused on the potential anorexigenic role of the LHA and $\mathrm{RCH}$. The role of the neuroendocrine $\mathrm{PVH}$ is addressed in the experiments described in the next section.

First, we examined how patterns of $\mathrm{CRH}$ and NT/N gene expression in the LHA and RCH were modified by DE and FR. In the LHA of intact-EU animals, the number of CRH mRNAcontaining cells was very low (Figs. $3 A, 4 A$ ). As anticipated, after $5 \mathrm{~d}$ of DE there was a highly significant increase in the numbers of positively labeled cells (Figs. $3 C, 4 A$ ) and the amount of $\mathrm{CRH}$ mRNA per cell (Fig. 4C) in the LHA-crh (Kelly and Watts, 1996, 1998). In contrast, pair-fed FR animals had levels of CRH mRNA that remained very low and indistinguishable from EU controls (Figs. 3E, 4A,C). There were already substantial numbers of $\mathrm{NT} / \mathrm{N}$ mRNA-containing neurons in LHA-crh of intact-EU animals (Figs. $3 B, 4 B$ ), and these were not significantly increased by DE (Figs. 3D, $4 B$ ) or FR (Figs. 3F, $4 B$ ). However, the amount of $\mathrm{NT} / \mathrm{N}$ mRNA per cell was significantly increased by DE only (Figs. $3 D, 4 D$ ). Figure $3 C, D$ shows that the majority of the $\mathrm{NT} / \mathrm{N}$ mRNA-containing neurons that showed increased mRNA levels in the LHA after DE were in the same region as those expressing $\mathrm{CRH}$ mRNA. In this regard, we have recently observed that $>90 \%$ of the $\mathrm{CRH}$ neurons in the LHA-crh also express NT/N mRNA (our unpublished observations). Although the overall number of neurons was much lower, the nature of the response of $\mathrm{CRH}$ and NT/N mRNA-containing neurons in the $\mathrm{RCH}$ was virtually identical to that seen in the LHA (Fig. 5; see also Fig. $8 B, D, F)$. Only in intact-DE animals were there significant increases in these mRNAs.

Second, we showed that the amount of CRH mRNA present in the LHA of DE animals on day 5 was significantly correlated with the degree of anorexia exhibited the previous night (Fig. 6A) $\left(r^{2}=0.876 ; F_{(10,1)}=63.7 ; p<0.0001\right)$. Third, the rapid reversal 

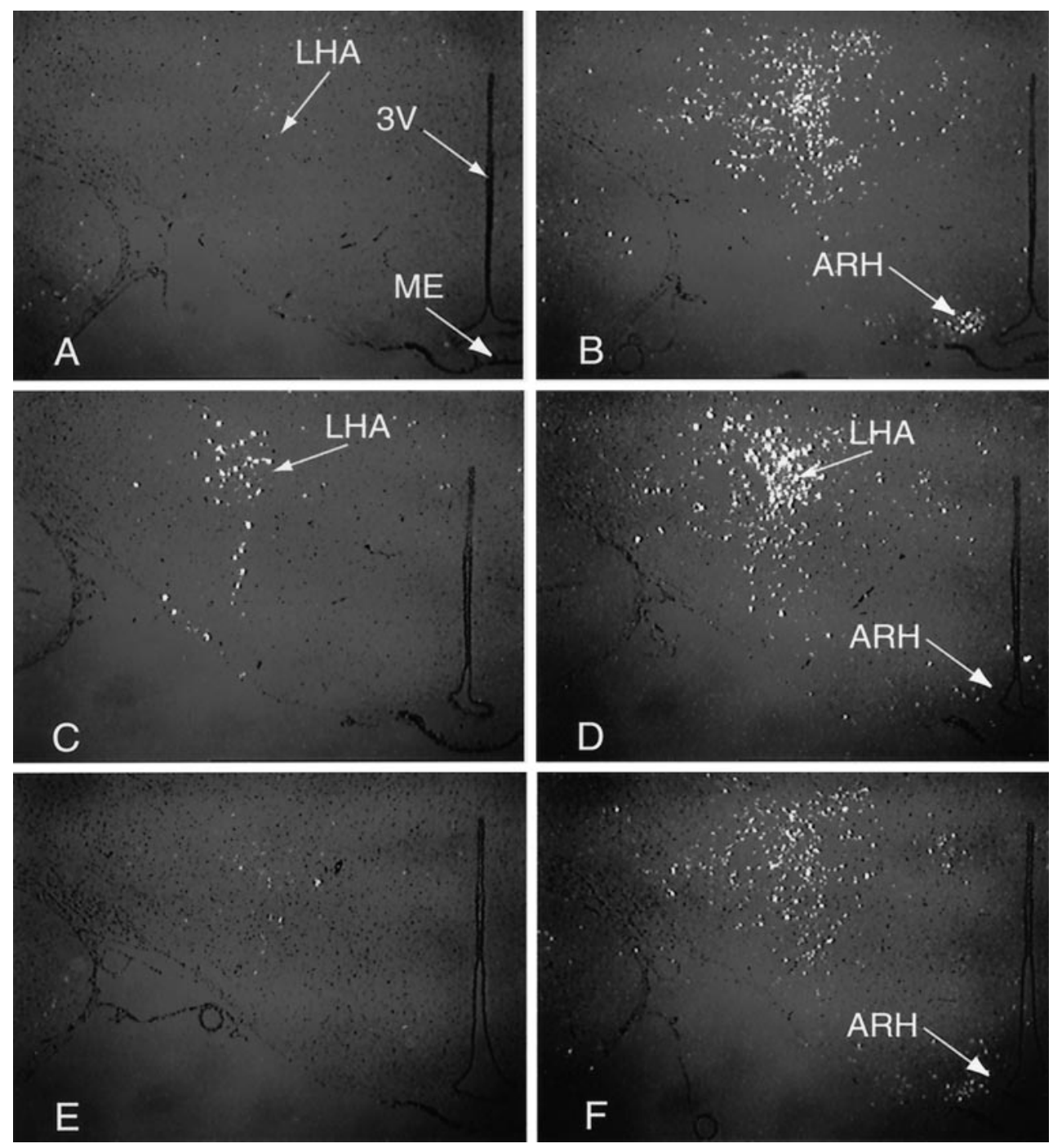

Figure 3. CRH and neurotensin mRNA hybridization in the lateral hypothalamic area. Dark-field photomicrographs of $\mathrm{CRH}(A, C, E)$ and $\mathrm{NT} / \mathrm{N}(B, D, F)$ mRNA hybridization in the lateral hypothalamic area $(L H A)$ and arcuate nucleus $(A R H)$ at approximately level 27/28 of Swanson (1992) of animals in the three treatment groups killed on treatment day 5. $A, B$, Serial sections from a control euhydrated animal; $C, D$, serial sections from a dehydrated animal; $E, F$, serial sections from a food-restricted animal. $3 \mathrm{~V}$, Third ventricle; $M E$, median eminence. of anorexia after the drinking of water (Watts, 1999) reduced CRH mRNA in the LHA to levels indistinguishable from EU animals $24 \mathrm{hr}$ but not $5 \mathrm{hr}$ after DE animals had been allowed access to water (Fig. 6B).

\section{CRH gene expression in the hypothalamic paraventricular nucleus of intact and adrenalectomized rats after dehydration and food restriction}

$\mathrm{CRH}$ neurons in the neuroendocrine $\mathrm{PVH}$ are implicated as potential regulators of ingestive behaviors (Schwartz et al., 1995; Woods et al., 1998). Starvation, FR, and DE all reportedly decrease CRH mRNA in the medial parvicellular part of the PVH (PVHmp) (Brady et al., 1990; Watts, 1996), and altered neuroendocrine CRH metabolism acting on adrenal corticosterone secretion is a potential mechanism through which anorexia might be generated (Woods et al., 1998). Consequently, in our final gene expression experiment we determined how DE and FR affected CRH mRNA in the medial parvicellular (neuroendocrine) part of the PVH of intact and ADX rats, and then how dehydration modified CRH mRNA in the PVH and LHA of ADX rats. We used ADX-DE rats because, in contrast to intact-DE animals, they do not show reduced $\mathrm{CRH}$ gene expression in the PVHmp
(Watts and Sanchez-Watts, 1995a). Although DE significantly reduced CRH mRNA levels in the PVHmp when compared with intact-EU animals, paired-FR had no effect; levels in these animals were indistinguishable from intact-EU controls (Figs. $7 A$, $8 A, C, E)$. However, despite ADX-DE animals having PVHmp levels of CRH mRNA that were indistinguishable from ADX-EU animals (Fig. 7B), they developed DE-associated anorexia at a rate identical to intact animals (Fig. $1 B$ ). Furthermore, Figure $7 C$ shows that CRH mRNA in the LHA of ADX-DE animals was significantly increased in a manner similar to that seen in ADX-EU animals. These CRH mRNA-containing neurons in ADX-DE animals were located in the same region of the LHAcrh as those seen in intact-DE animals (data not shown).

\section{Projections from the LHA-crh to the hypothalamic paraventricular nucleus}

The generation of DE-associated anorexia by peptidergic LHAcrh neurons would require that their afferent projections interact with elements of those neural networks previously implicated in controlling food intake. One such locus is the PVH, which receives inputs from the ARH critical for increasing food intake (for review, see Elmquist et al., 1998a). To determine whether the $\mathrm{PVH}$ is a region that received afferents from the LHA-crh as 
A)

Figure 4. Dehydration and food restriction differentially affect gene expression in the lateral hypothalamic area. Mean $( \pm$ SEM) levels of CRH $(A, C)$ and NT/N $(B, D)$ mRNA hybridization measured on treatment day 5 in the lateral hypothalamic area of euhydrated $(E U)$, dehydrated $(D E)$, and paired-food restricted $(F R)$ animals. $A$, $B$, Total pixel area of the specific hybridization signal; $C, D$, the mean gray level of the specifically labeled area. See Materials and Methods for further details of the image analysis. ${ }^{*} p<0.0025$; ${ }^{* *} p<0.0005 ;{ }^{* * *} p<$ 0.0001 versus EU animals.

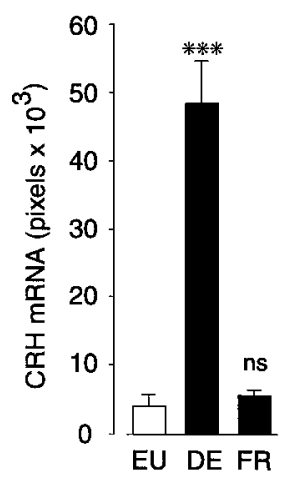

might be a potential site of integration, we injected PHA-L into the LHA-crh of DE rats.

Only those injections centered in the LHA-crh region (cases LP 6, 10, 14) resulted in labeled fibers in the PVH. The results from case LP 6 are shown in Figures 9 and 10. Although fibers and structures indicative of terminal boutons were visible in both the magnocellular and parvicellular neuroendocrine parts of the $\mathrm{PVH}$, they were most abundant in the dorsal, ventral, and lateral parvicellular regions of the $\mathrm{PVH}$ that are known to contain neurons projecting to the brainstem and spinal cord. These fibers appeared to course to the more rostral regions of the $\mathrm{PVH}$ through the lateral parvicellular PVH [LP 6 level 27 (Figs. 9, 10)]. In contrast, injections of PHA-L placed beyond the limits of LHA-crh [cases LP3, 15, and 18 (Fig. 9); case LP18 (Fig. 10)] showed far weaker projections into the PVH, with fibers aggregating just outside the borders of the nucleus. This was particularly prominent in case LP18 (Figs. 9, 10), where the injection was located immediately medial to the fornix (Kelly and Watts, 1998). Injections placed within the same mediolateral limits as the LHA-crh, but located either more rostrally or caudally, also had far fewer labeled fibers in the PVH than injections in the LHAcrh [cases LP 15 and 3 (Fig. 9)].

\section{DISCUSSION}

We have shown that for those hypothalamic neuropeptide genes whose products can regulate feeding, hunger and anorexia result

\section{A)}

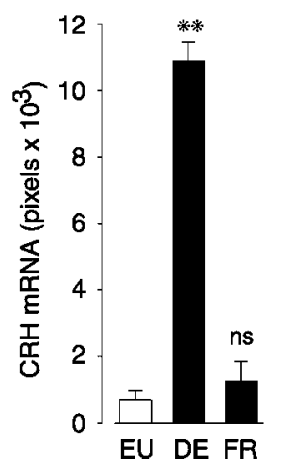

B)

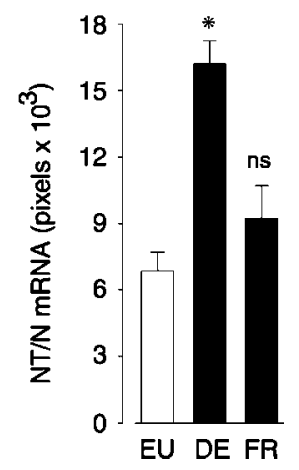

B)

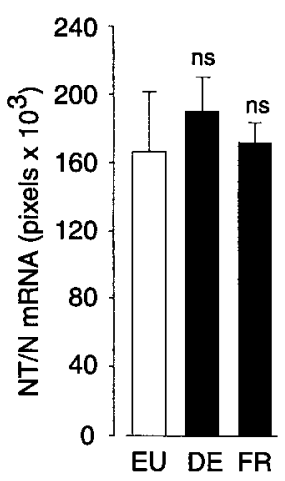

C)

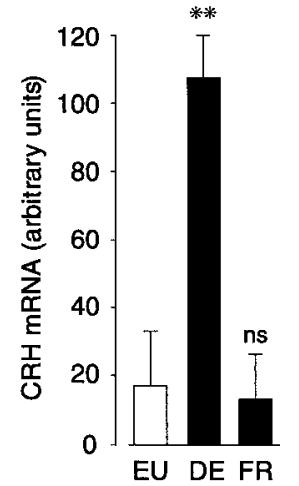

D)

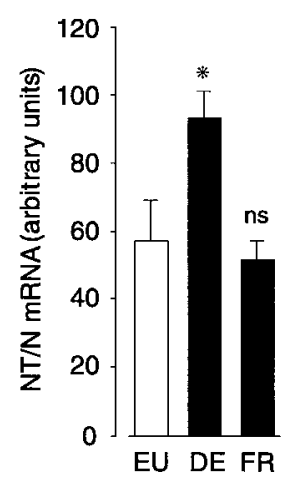

in two expression patterns. Figure 11 shows that some of these alterations are specific to DE-associated anorexia, others happen in both hunger and anorexia, and all occur in key components of a hypothalamic network critical for regulating eating: the LHA, ARH, RCH, and PVH. We also demonstrate that those peripheral signals usually processed centrally to stimulate eatingreduced leptin and insulin, and elevated corticosterone concentrations-occur in both hungry and anorexic animals and likely initiate the altered NPY, POMC, and possibly NT/N gene expression seen in the ARH after both behavioral challenges (Schwartz et al., 1996, 1997; Sahu, 1998). Considering that DE produces strong anorexia, the presence of this humoral signal pattern is superficially paradoxical. However, these profiles are consistent with a model we have proposed to explain the sequence of rat ingestive behaviors seen as dehydration-associated anorexia develops and is then rapidly reversed by drinking water (Watts, 1999). This model posits that by generating anorexia, DE ultimately impacts two sets of neural circuits responsible for
A)

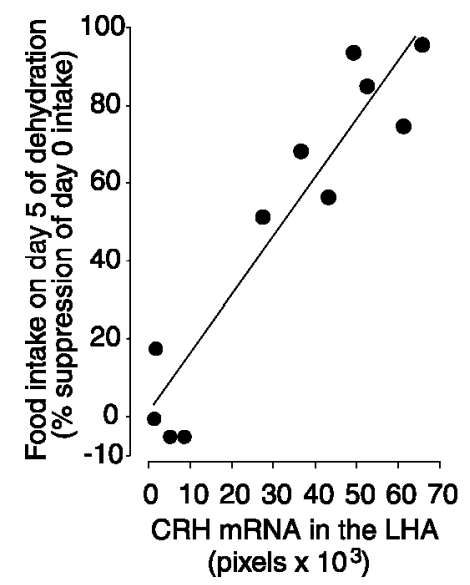

B)

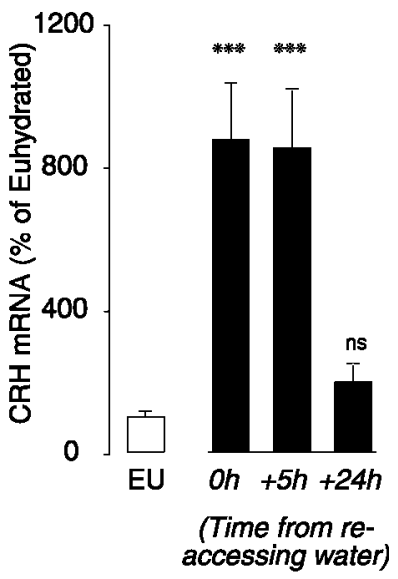

Figure 6. CRH mRNA in the LHA is correlated with the degree of anorexia, and CRH mRNA levels in the LHA return to control values 24 $\mathrm{hr}$ after anorexia is reversed. $A$, Correlation between food intake (expressed as the percentage reduction relative to that measured during the dark period immediately preceding treatment day 0 ) and total pixel area of the specific CRH mRNA hybridization signal measured on treatment day 5 in individual euhydrated and dehydrated rats. See Results for levels of significance. $B$, Mean $( \pm$ SEM) CRH mRNA hybridization signal in the lateral hypothalamic area of animals before $(0 \mathrm{hr}), 5 \mathrm{hr}$, or $24 \mathrm{hr}$ after the return of drinking water. Values were measured as total pixel area and expressed as a percentage relative to those in euhydrated $(E U)$ animals on treatment day 5. $* * * p<0.00025$ versus EU animals. $n s$, Not significant.
Figure 5. Dehydration and food restriction differentially affect gene expression in the retrochiasmatic area. Mean $( \pm$ SEM) levels of CRH $(A)$ and NT/N $(B)$ mRNA hybridization measured on treatment day 5 in the food restricted $(F R)$ animals. See Materials and Methods for further details of the image analysis. ${ }^{*} p<0.005 ;{ }^{*} p<0.0001$ versus EU. $n s$, Not significant. retrochiasmatic area of euhydrated $(E U)$, dehydrated $(D E)$, and paired- 

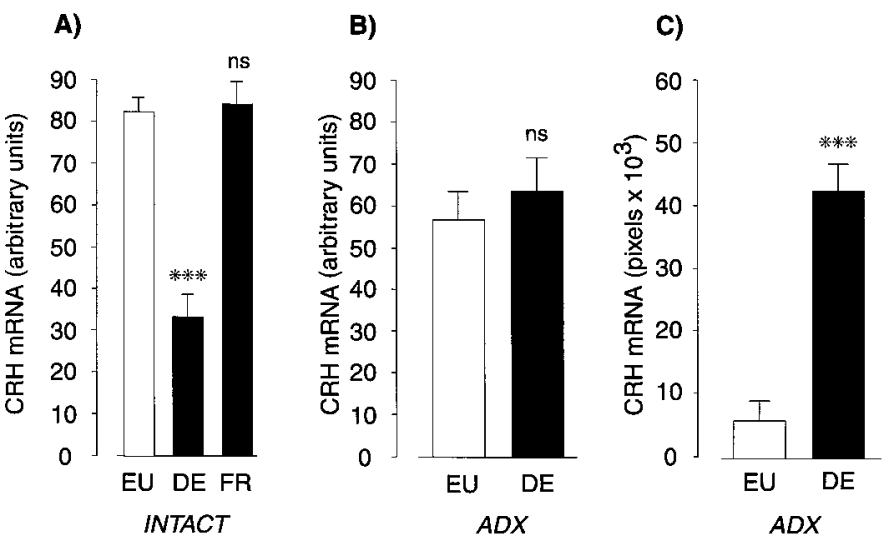

Figure 7. Dehydration and food-restriction effects on CRH gene expression in the paraventricular nucleus and lateral hypothalamic area of adrenalectomized rats. Mean $( \pm$ SEM) levels of CRH mRNA hybridization measured on treatment day 5 in the dorsal aspect of the medial parvicellular part of the hypothalamic paraventricular nucleus from euhydrated $(E U)$, dehydrated $(D E)$, paired-food restricted $(F R)$ intact animals $(A)$, or from EU or DE adrenalectomized $(A D X)(B)$ animals. $C$, Mean $( \pm$ SEM) levels of CRH mRNA hybridization in the lateral hypothalamic area of EU or DE-ADX animals. See Materials and Methods for further details of the image analysis. ${ }^{* * *} p<0.0005$ versus EU animals. $n s$, Not significant.

regulating eating behavior. The first is responsible for stimulating the eating that normally follows periods of negative energy balance, and the similar pattern of modified gene expression evident in the ARH of both DE and FR rats is consistent with this hypothesis. However, during DE but not FR, the motor output of this stimulatory network is inhibited by a second set of neural circuits that involves neuropeptides in particular parts of the LHA and RCH. This inhibition is removed minutes after the return of water by an as yet unknown but clearly fast-acting mechanism (Watts, 1999).

\section{Retrochiasmatic and lateral hypothalamic neuropeptides in the generation of anorexia}

The integrated output of LHA neurons normally stimulates eating (for review, see Elmquist et al., 1999), the substrate of which probably includes the large but distinct populations of hypocretin/orexin- and MCH-containing neurons in LHA (Broberger et al., 1998; Elias et al., 1998b). However, because excitotoxic LHA lesions cause mild rather than catastrophic hypophagia and do not impede compensatory responses after deprivation (Winn, 1995), its overall function is clearly not mandatory but has a more subtle and modulatory nature (Winn, 1995; Sawchenko, 1998). Additional support for this notion derives from the presence of at least two neuropeptides in the LHA of normally fed animals (neurotensin and CART) that will inhibit eating if exogenously applied (Levine et al., 1983; Kristensen et al., 1998). Considered in this manner, it seems likely that this diverse neuropeptidergic output of the LHA can be differentially modulated by its array of afferents (Kelly and Watts, 1996), has the capacity to regulate feeding in a wide variety of circumstances, and in some instances can generate anorexia.

Our results strongly implicate increased $\mathrm{CRH}$ and neurotensin activity in discrete populations of LHA and $\mathrm{RCH}$ neurons as mediators of DE-associated anorexia. Together, the following findings advocate a novel anatomical substrate in the LHA and $\mathrm{RCH}$ for the well known anorexigenic actions of CRH. First, elevated CRH mRNA only occurs in DE animals that develop
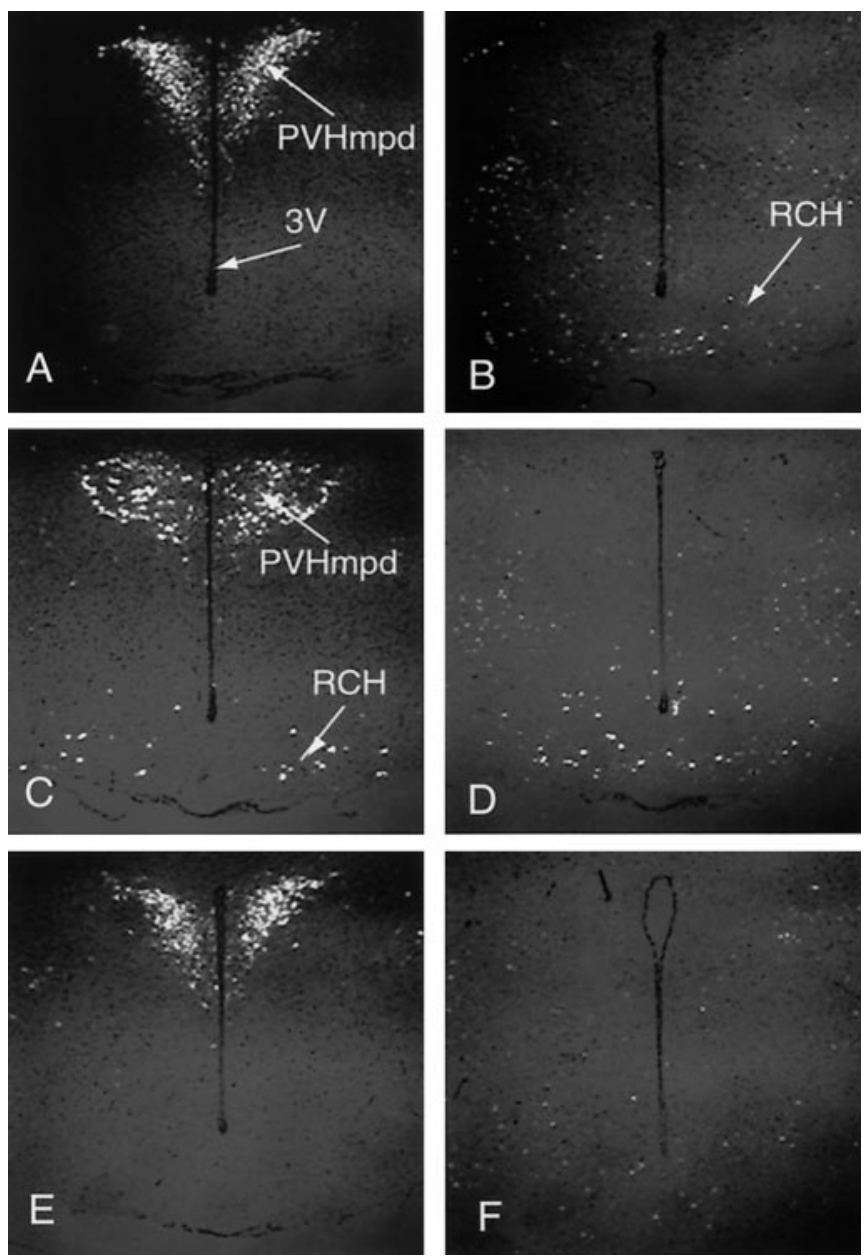

Figure 8. CRH and neurotensin mRNA hybridization in the paraventricular nucleus retrochiasmatic area. Dark-field photomicrographs of $\mathrm{CRH}(A, C, E)$ and NT/N $(B, D, F)$ mRNA hybridization in the paraventricular nucleus $(\mathrm{PVH})$ and retrochiasmatic area $(\mathrm{RCH})$ at approximately level 25/26 of Swanson (1992) of animals in the three treatment groups killed on treatment day 5. $A, B$, Serial sections from a control euhydrated animal; $C, D$, sections from a dehydrated animal; $E, F$, sections from a food-restricted animal. $3 \mathrm{~V}$, Third ventricle; PVHmpd, dorsal aspect of the medial parvicellular part of the PVH.

anorexia and not in pair-fed FR animals. Second, the amount of CRH mRNA in the LHA is significantly correlated to the intensity of expressed anorexia. Third, CRH mRNA dynamics in the LHA are consistent with a role in generating anorexia: its appearance anticipates the onset of anorexia (Watts et al., 1995; Watts, 1999), and the extinction of anorexia by drinking water is followed within $24 \mathrm{hr}$ by a return of CRH mRNA to control levels (this study). Fourth, DE reveals CRH-immunoreactive neurons in these same LHA and RCH regions (Kay-Nishiyama and Watts, 1999). Finally, intraventricular injections of CRH and neurotensin inhibit deprivation-induced eating but do not stimulate drinking (Levine et al., 1983; Morley, 1987), demonstrating that elevated CRH and NT/T mRNAs in DE animals are unlikely to contribute directly to increases in thirst.

Interestingly, this anorexia is independent of alterations in both plasma corticosterone and $\mathrm{CRH}$ gene expression in $\mathrm{PVH}$ neuroendocrine neurons because DE-ADX animals also develop anorexia despite the absence of corticosterone and altered CRH gene expression in the PVH (Watts and Sanchez-Watts, 1995a; 
Level 26
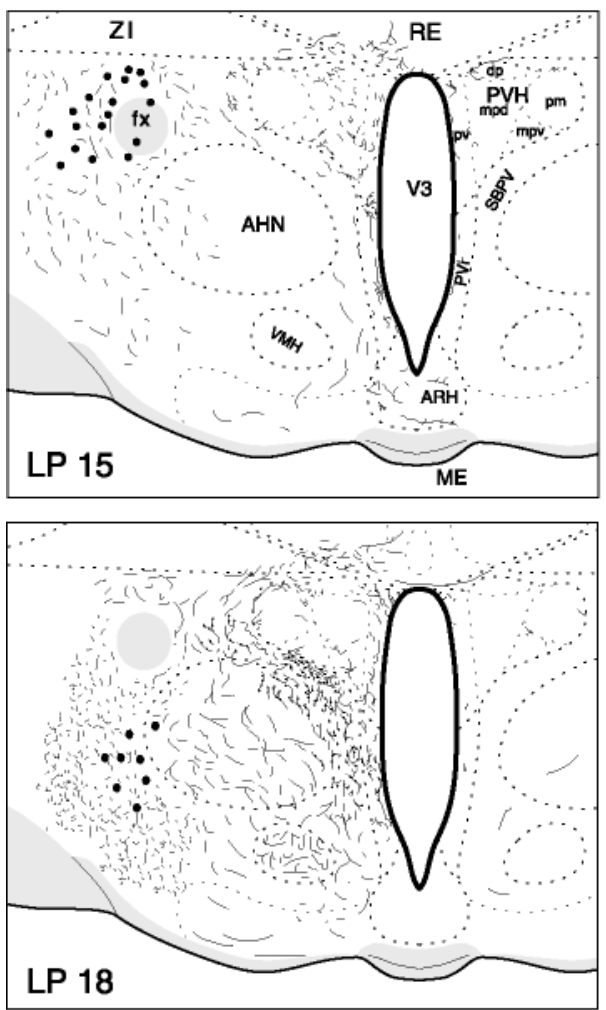

Figure 9. Maps of PHAL-labeled projections from the lateral hypothalamic area to the paraventricular nucleus. PHALimmunoreactive processes from four representative injections plotted onto maps at levels 26 and 27 of Swanson (1992). PHAL immunoreactively labeled neuronal cell bodies at injection sites (black dots) are also shown where visible. Maps are arranged depending on the rostrocaudal position of the injection site, with the most rostral case (LP 15) first. Cases LP 15, LP 18, and LP 3 (located at the same dorsoventral position as the LHA-crh, but further caudal at level 29) were all control injections placed outside the region of the LHA-crh; case LP 6 was in the center of the LHA-crh [Level 27A (Kelly and Watts, 1998)]. Note the large number of PHAL-labeled fibers in the parvicellular regions of the $\mathrm{PVH}$ in case LP 6, but not in any of the control injections. See Kelly and Watts (1998) for complete descriptions of the injection sites. $3 \mathrm{~V}$, Third ventricle; $A H N$, anterior hypothalamic nucleus; $A R H$, arcuate nucleus; $d p$, dorsal parvicellular part of the $\mathrm{PVH} ; f x$, fornix; $l p$, lateral parvicellular part of the $\mathrm{PVH} ; \mathrm{mpd}$, dorsal aspect of the medial parvicellular part of the PVH; $m p v$, ventral aspect of the medial parvicellular part of the $\mathrm{PVH} ; p v$, periventricular part of the $\mathrm{PVH}$; $R E$, nucleus reuniens; $S B P V$, subparaventricular zone; $V M H$, ventromedial nucleus; $Z I$, zona incerta.
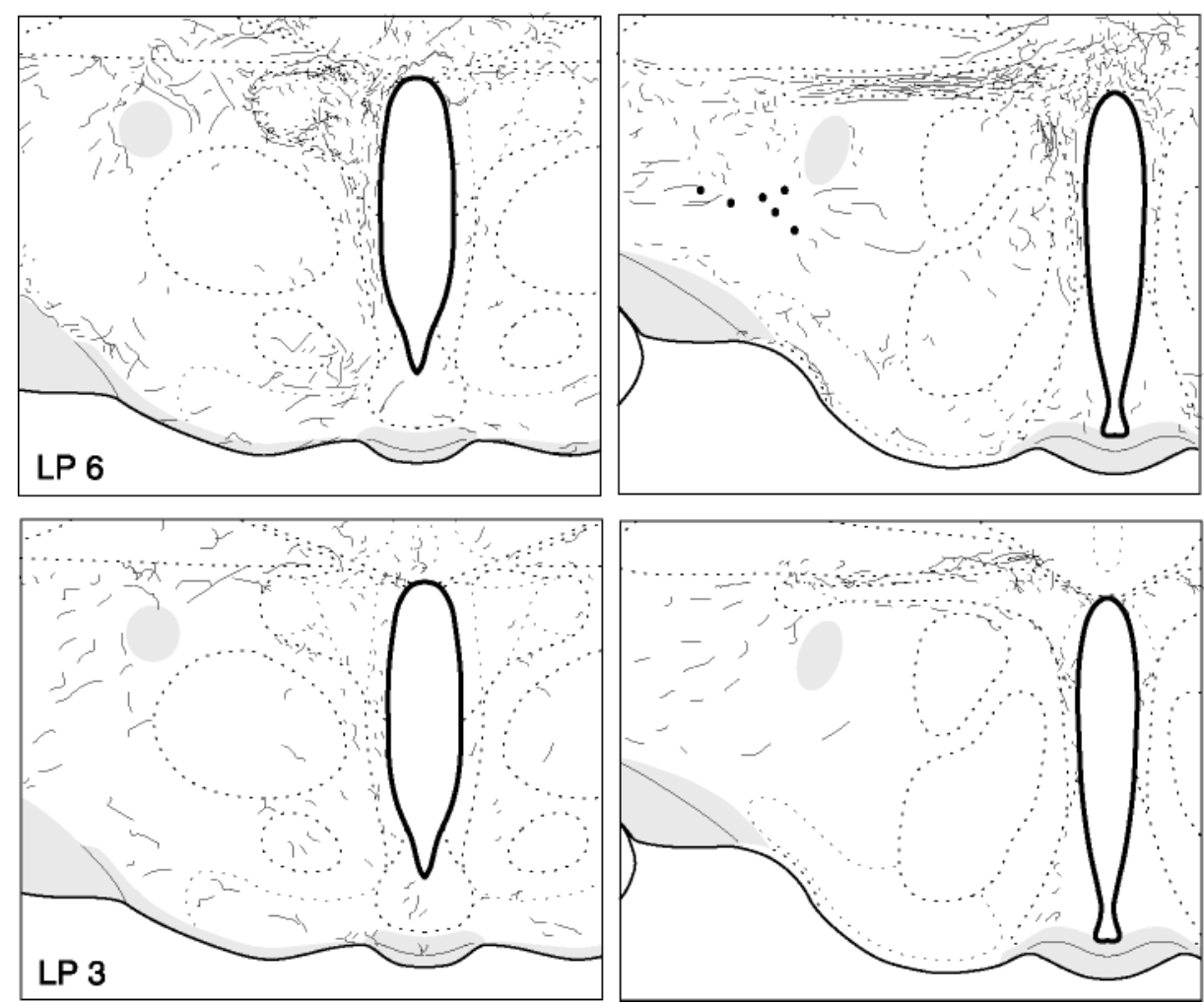

this study). The fact that ADX-DE rats have increased $\mathrm{CRH}$ mRNA in the LHA and RCH expressed with an identical topography to intact-DE animals is consistent with an anorexiagenerating role for these neurons.

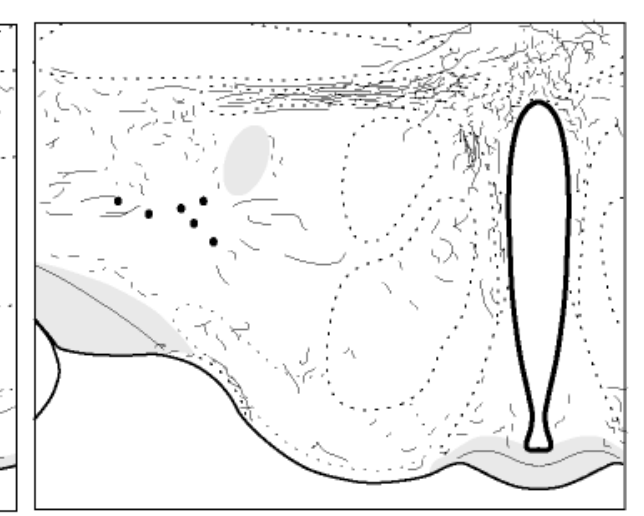

Level 27
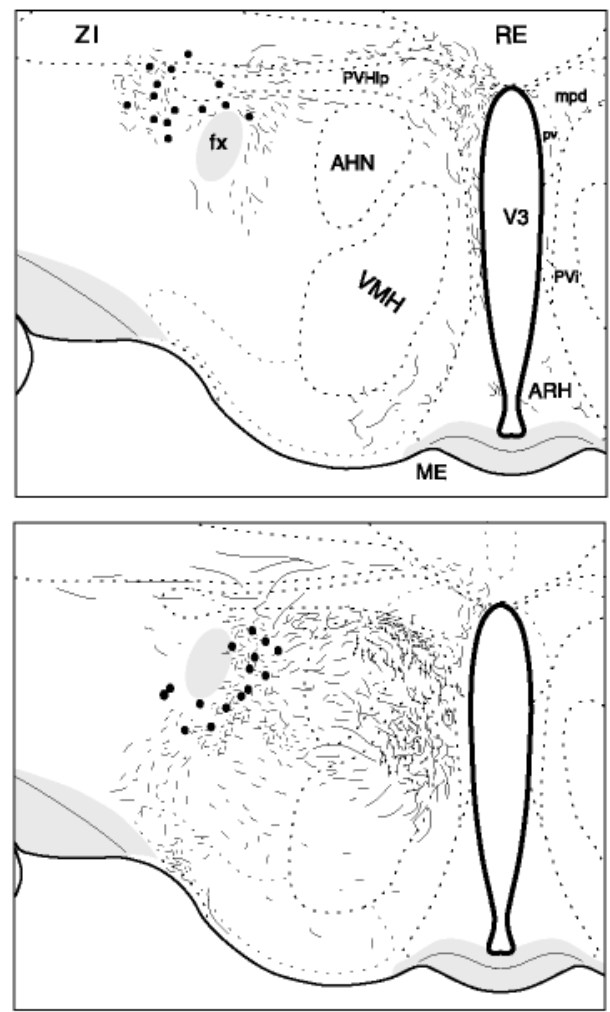

The arcuate nucleus and the stimulation of food intake The ARH is a central component of the neural network that regulates eating. It is a major target of leptin signaling (Schwartz et al., 1997; Elmquist et al., 1998b; Hakansson et al., 1998; Sahu, 
Level 26

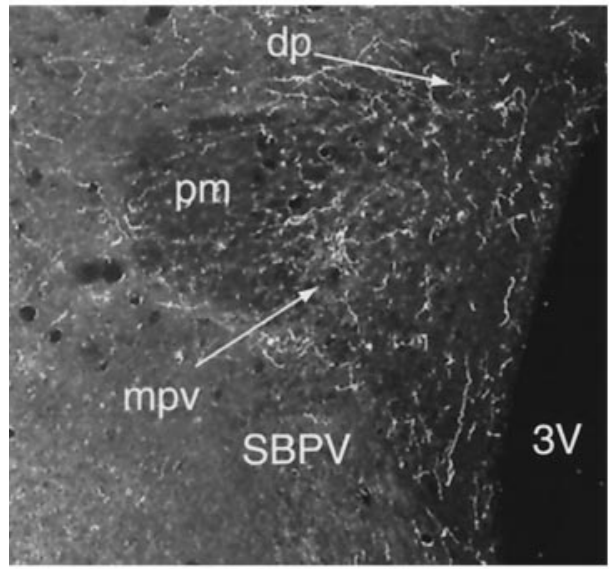

A)
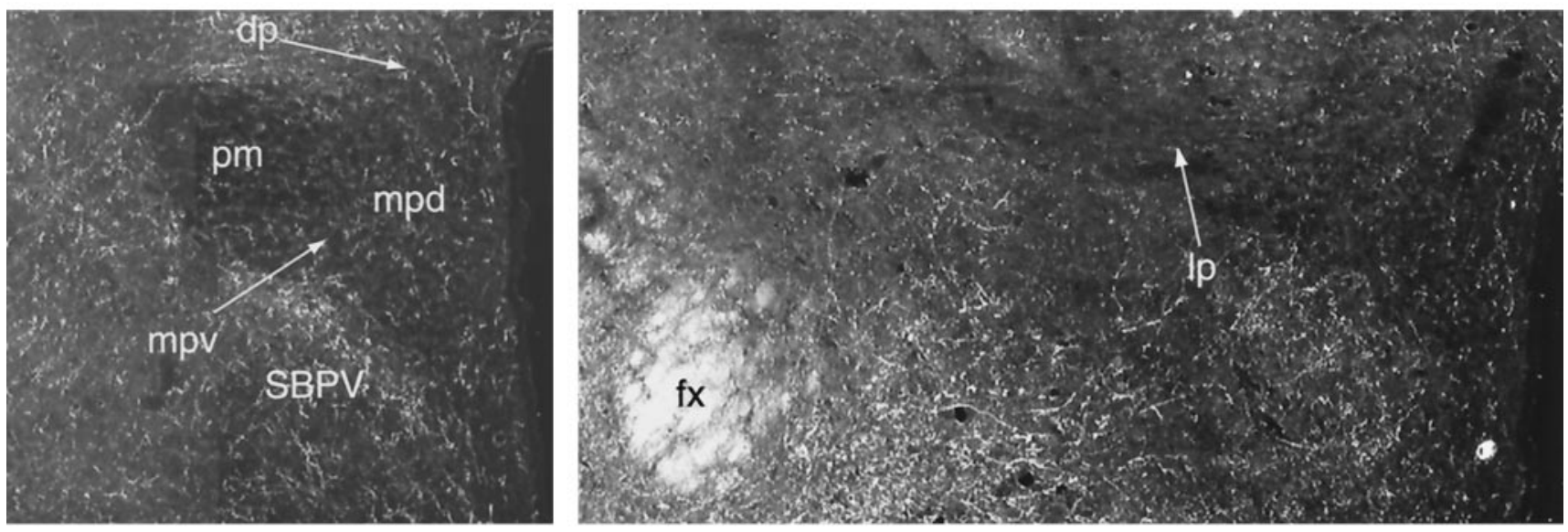

\section{Level 27}

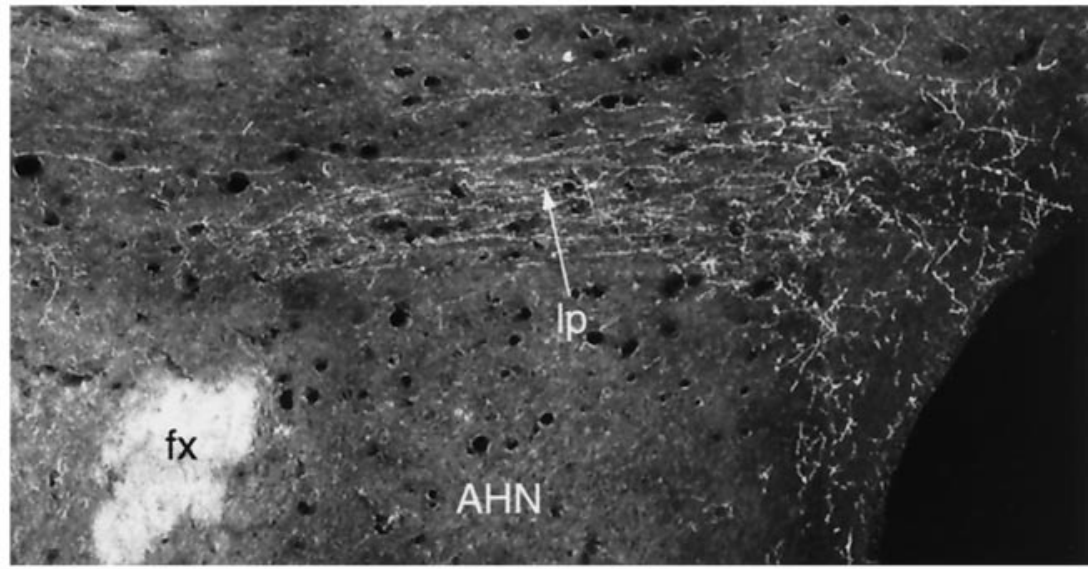

B)

Figure 10. PHAL-labeled projections from the lateral hypothalamic area to the paraventricular nucleus. Dark-field photomicrographs of PHALimmunoreactive processes in the region of the hypothalamic paraventricular nucleus (PVH) at approximately levels 26 and 27 of Swanson (1992). Injection LP $6(A)$ was centered in the LHA-crh (level 27A/28); case LP $18(B)$ was a control injection centered in the region immediately medial and ventral to the fornix at level 26/27 of Swanson (1992). Note the large number of PHAL-labeled fibers in the parvicellular regions of the PVH in the animal injected in the LHA-crh $(A)$ but not the control injection $(B)$. See Kelly and Watts $(1998)$ for further detailed descriptions of the injection sites. $3 V$, Third ventricle; $A H N$, anterior hypothalamic nucleus; $d p$, dorsal parvicellular part of the PV H; $f x$, fornix; lp, lateral parvicellular part of the PVH; $m p d$, dorsal aspect of the medial parvicellular part of the PVH; $m p v$, ventral aspect of the medial parvicellular part of the PVH; SBPV, subparaventricular zone.

1998), and substantial evidence implicates ARH neuropeptides as critical determinants of eating. Thus, central injections of NPY stimulate eating (Stanley and Leibowitz, 1985), elevated NPY mRNA occurs after FR or deprivation (Brady et al., 1990; Woods et al., 1998), MC3/4 receptor agonists inhibit eating (Fan et al., 1997; Thiele et al., 1998), and manipulating circulating leptin alters the expression of neuropeptide genes in the ARH (Schwartz et al., 1997; Sahu, 1998). Here we show that a pairfeeding schedule mirroring the amount of food eaten during DE has virtually the same effects on the levels of NPY, POMC, and $\mathrm{NT} / \mathrm{N}$ mRNAs as DE itself, suggesting that these gene responses are a consequence of the reduced food intake common to both treatments and are unlikely to be the substrate for anorexia. Although changes in NPY, POMC, and NT/N mRNA levels have been reported previously after DE or FR (Brady et al., 1990; O'Shea and Gundlach, 1995; Watts et al., 1995), this is the first study to compare directly the effects of DE with paired FR on these variables.

\section{The paraventricular nucleus and the integration of feeding signals}

During the development and rapid termination of DE-associated anorexia, accounting for the operational dynamics of the two neural networks impacted by dehydration (one inhibiting, the other stimulating eating) requires their eventually convergence. Several lines of evidence place the $\mathrm{PVH}$ in a strategic position to effect at least part of this integration (Gold, 1973; Stanley and Leibowitz, 1985), including the fact that insulin and leptinsensitive NPY neurons in the ARH provide afferents to the PVH (Kalra et al., 1991; Elmquist et al., 1999). Our findings that FR and DE similarly affect NPY gene expression is consistent with ARH-PVH projections being components of the stimulatory 


\section{Anorexia only}

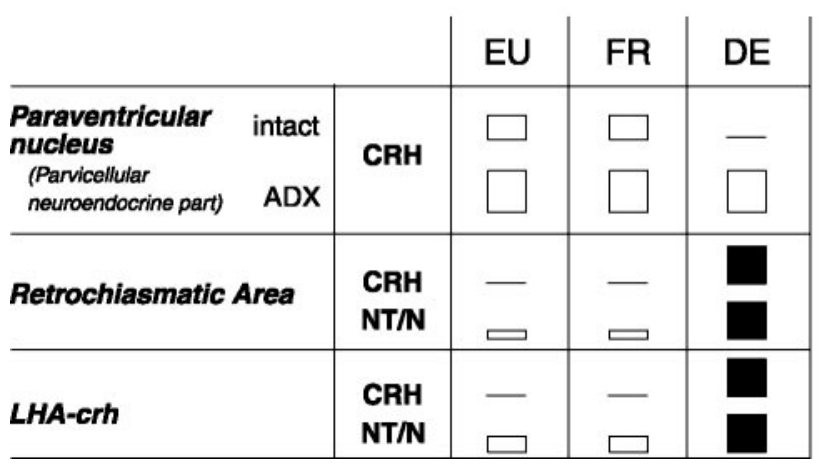

Hunger and Anorexia

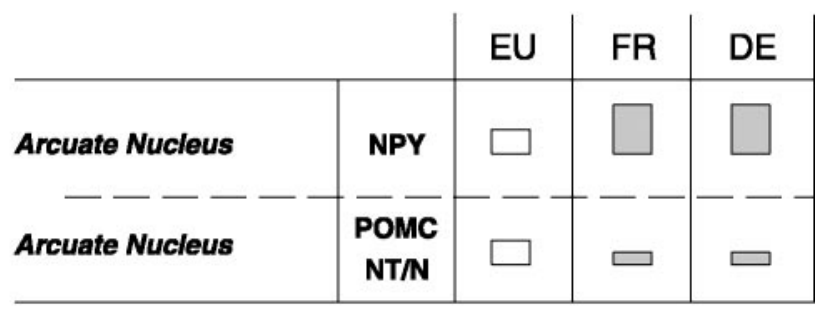

Figure 11. Summary of changes in gene expression. Schematic diagram summarizing those patterns of gene expression that are exclusive to dehydrated (anorexic) animals (black bars) and those that are common to both dehydrated and food-restricted (hungry) animals (gray bars). The height of each symbol represents relative levels of gene expression.

network described above. To incorporate an inhibitory network, we now show that the region of the LHA expressing CRH during DE specifically provides efferents to parvicellular PVH subdivisions consistent with the data of Larsen et al. (1994). It is notable that some of these same regions contain preganglionic neurons capable of regulating a wide variety of behavioral and autonomic motor functions (Swanson, 1987). That CRH functions in this LHA-PVH pathway is supported by the fact that some CRH neurons in the perifornical LHA project to the PVH (Champagne et al., 1998). A functional interaction of this kind is also supported by the observation that feeding induced by injections of NPY into the PVH is inhibited by CRH (Heinrichs et al., 1993).

Finally, it is worth noting that in addition to actions at the PVH, DE-sensitive CRH neurons in the LHA may also have modulatory actions in the parabrachial nucleus and other brainstem loci known to be involved with energy metabolism and gustation (Moga et al., 1990; Kelly and Watts, 1998). Although it is likely that other neuropeptides in the LHA and $\mathrm{RCH}$ (e.g., $\mathrm{MCH}$, orexin/hypocretin, CART, POMC) contribute to altered motor function in these networks (Elias et al., 1998a), their role in the generation and recovery from DE-associated anorexia is currently unknown.

Considered together, our data from DE and FR animals are consistent with our previously proposed model for DE-associated anorexia (Watts, 1999). Thus, during the first night of drinking hypertonic saline, information about increasing plasma osmolality is relayed to neurons in the LHA using projections from the lamina terminalis. In turn, this activates $\mathrm{CRH}$ and $\mathrm{NT} / \mathrm{N}$ genes (Kelly and Watts, 1996), although at this time it is insufficient to provoke anorexia (Watts, 1999), but as the intensity of dehydration increases, elevated CRH and neurotensin in LHA efferents now act, possibly at the PVH, to suppress feeding. This progressive suppression of feeding provokes the characteristic hormonal and ARH neuropeptide signature of negative energy balance, accounting for the similar responses to FR and DE. However, during DE, steadily increasing inhibition from $\mathrm{CRH}$ and neurotensin neural signaling prevents these elements from stimulating eating. When water is again drunk, sensory components of this action rapidly disinhibit the stimulatory network, provoking avid food consumption (Watts, 1999). As drinking water continues, plasma osmolality falls (Hatton and Bennett, 1970), allowing LHA CRH gene expression and normal feeding patterns to return to control levels (Watts, 1999; this study). These results suggest that the behavioral and neuropeptidergic aspects of DEassociated anorexia provide a very powerful dynamic paradigm for investigating the neural basis of ingestive behaviors.

\section{REFERENCES}

Brady LS, Smith MA, Gold PW, Herkenham M (1990) Altered expression of hypothalamic neuropeptide mRNAs in food-restricted and food-deprived rats. Neuroendocrinology 52:441-447.

Broberger C, De Lecea L, Sutcliffe JG, Hokfelt T (1998) Hypocretin/ orexin- and melanin-concentrating hormone-expressing cells form distinct populations in the rodent lateral hypothalamus: relationship to the neuropeptide $\mathrm{Y}$ and agouti gene-related protein systems. J Comp Neurol 402:460-474.

Champagne D, Beaulieu J, Drolet G (1998) CRFergic innervation of the paraventricular nucleus of the rat hypothalamus: a tract-tracing study. J Neuroendocrinol 10:119-131.

Drouin J, Goodman HM (1980) Most of the coding region of rat ACTH beta-LPH precursor gene lacks intervening sequences. Nature 288:610-613.

Elias CF, Lee C, Kelly J, Aschkenasi C, Ahima RS, Couceyro PR, Kuhar MJ, Saper CB, Elmquist JK (1998a) Leptin activates hypothalamic CART neurons projecting to the spinal cord. Neuron 21:1375-1385.

Elias CF, Saper CB, Maratos-Flier E, Tritos NA, Lee C, Kelly J, Tatro JB, Hoffman GE, Ollmann MM, Barsh GS, Sakurai T, Yanagisawa M, Elmquist JK (1998b) Chemically defined projections linking the mediobasal hypothalamus and the lateral hypothalamic area. J Comp Neurol 402:442-459.

Elmquist JK, Maratos-Flier E, Saper CB, Flier JS (1998a) Unraveling the central-nervous-system pathways underlying responses to leptin. Nat Neurosci 1:445-450.

Elmquist JK, Bjorbaek C, Ahima RS, Flier JS, Saper CB (1998b) Distributions of leptin receptor mRNA isoforms in the rat brain. J Comp Neurol 395:535-547.

Elmquist JK, Ahima RS, Elias CF, Flier JS, Saper CB (1998c) Leptin activates distinct projections from the dorsomedial and ventromedial hypothalamic nuclei. Proc Natl Acad Sci USA 95:741-746.

Elmquist JK, Elias CF, Saper CB (1999) From lesions to leptin: hypothalamic control of food intake and body weight. Neuron 22:1-20.

Fan W, Boston BA, Kesterson RA, Hruby VJ, Cone RD (1997) Role of melanocortinergic neurons in feeding and the agouti obesity syndrome. Nature 385:165-168.

Frim DM, Robinson BG, Pasieka KB, Majzoub JA (1990) Differential regulation of corticotropin-releasing hormone mRNA in rat brain. Am J Physiol 258:E686-E692.

Gold PW (1973) Hypothalamic obesity: the myth of the ventromedial nucleus. Science 182:488-490.

Hakansson ML, Brown H, Ghilardi N, Skoda RC, Meister B (1998) Leptin receptor immunoreactivity in chemically defined target neurons of the hypothalamus. J Neurosci 18:559-572.

Hatton GI, Bennett CT (1970) Satiation of thirst and termination of 
drinking roles of plasma osmolality and absorption. Physiol Behav $5: 479-487$.

Heinrichs SC, Menzaghi F, Pich EM, Hauger RL, Koob GF (1993) Corticotropin-releasing factor in the paraventricular nucleus modulates feeding induced by neuropeptide-Y. Brain Res 611:18-24.

Hruby VJ, Lu D, Sharma SD, Castrucci AL, Kesterson RA, al-Obeidi FA, Hadley ME, Cone RD (1995) Cyclic lactam alpha-melanotropin analogues of Ac-Nle4-cyclo[Asp5, D-Phe7,Lys10] alpha-melanocytestimulating hormone-(4-10)-NH2 with bulky aromatic amino acids at position 7 show high antagonist potency and selectivity at specific melanocortin receptors. J Med Chem 38:3454-3461.

Huszar D, Lynch CA, Fairchild-Huntress V, Dunmore JH, Fang Q, Berkemeier LR, Gu W, Kesterson RA, Boston BA, Cone RD, Smith FJ, Campfield LA, Burn P, Lee F (1997) Targeted disruption of the melanocortin-4 receptor results in obesity in mice. Cell 88:131-141.

Kalra SP, Dube MG, Sahu A, Phelps CP, Kalra PS (1991) Neuropeptide $Y$ secretion increases in the paraventricular nucleus in association with increased appetite for food. Proc Natl Acad Sci USA 88:10931-10935.

Kay-Nishiyama C, Watts AG (1999) Dehydration modifies somal CRH immunoreactivity in the rat hypothalamus: an immunocytochemical study in the absence of colchicine. Brain Res 822:251-255.

Kelly AB, Watts AG (1996) The mediation of dehydration-induced peptidergic gene expression in the rat lateral hypothalamic area by forebrain afferent projections. J Comp Neurol 370:231-246.

Kelly AB, Watts AG (1998) The region of the pontine parabrachial nucleus is a major target of dehydration-sensitive $\mathrm{CRH}$ neurons in the rat lateral hypothalamic area. J Comp Neurol 394:48-63.

Kislauskis E, Dobner PR (1990) Mutually dependent response elements in the cis-regulatory region of the neurotensin/neuromedin $\mathrm{N}$ gene integrate environmental stimuli in PC12 cells. Neuron 4:783-795.

Kristensen P, Judge ME, Thim L, Ribel U, Christjansen KN, Wulff BS, Clausen JT, Jensen PB, Madsen OD, Vrang N, Larsen PJ, Hastrup S (1998) Hypothalamic CART is a new anorectic peptide regulated by leptin. Nature 393:72-76.

Larhammar D, Ericsson A, Persson H (1987) Structure and expression of the rat neuropeptide Y gene. Proc Natl Acad Sci USA 84:2068-2072.

Larsen PJ, Hay-Schmidt A, Mikkelsen JD (1994) Efferent connections from the lateral hypothalamic region and the lateral preoptic area to the hypothalamic paraventricular nucleus of the rat. J Comp Neurol 342:299-319.

Levine AS, Kneip J, Grace M, Morley JE (1983) Effect of centrally administered neurotensin on multiple feeding paradigms. Pharmacol Biochem Behav 18:19-23.

Moga MM, Saper CB, Gray TS (1990) Neuropeptide organization of the hypothalamic projection to the parabrachial nucleus in the rat. J Comp Neurol 295:662-682.

Morley JE (1987) Neuropeptide regulation of appetite and weight. Endocr Rev 8:256-287.

O'Shea RD, Gundlach AL (1995) NPY mRNA and peptide immunoreactivity in the arcuate nucleus are increased by osmotic stimuli: correlation with dehydration anorexia. Peptides 16:1117-1125.

Sahu A (1998) Evidence suggesting that galanin (GAL), melaninconcentrating hormone $(\mathrm{MCH})$, neurotensin $(\mathrm{NT})$, proopiomelanocortin (POMC) and neuropeptide Y (NPY) are targets of leptin signaling in the hypothalamus. Endocrinology 139:795-798.

Sawchenko PE (1998) Towards a new neurobiology of energy balance, appetite and obesity: the anatomists weigh in. J Comp Neurol 402:435-441.

Schwartz MW, Dallman MF, Woods SC (1995) Hypothalamic response to starvation: implications for the study of wasting disorders. Am J Physiol 269:R949-R957.

Schwartz MW, Seeley RJ, Campfield LA, Burn P, Baskin DG (1996) Identification of targets of leptin action in rat hypothalamus. J Clin Invest 98:1101-1106.

Schwartz MW, Seeley RJ, Woods SC, Weigle DS, Campfield LA, Burn P, Baskin DG (1997) Leptin increases hypothalamic proopiomelanocortin messenger-RNA expression in the rostral arcuate nucleus. Diabetes 46:2119-2123.

Stanley BG, Leibowitz SF (1985) Neuropeptide Y injected in the paraventricular hypothalamus: a powerful stimulant of feeding behavior. Proc Natl Acad Sci USA 82:3940-3943.

Stricker EM (1990) Homeostatic origins of ingestive behavior. In: Neurobiology of food and fluid intake. Handbook of behavioral neurobiology, Vol 10 (Stricker EM, ed), pp 45-60. New York: Plenum.

Swanson LW (1987) The hypothalamus. In: Handbook of chemical neuroanatomy, Vol 5 (Bjorklund A, Hökfelt T, Swanson LW, eds), pp 1-124. Amsterdam: Elsevier Science Publishers.

Swanson LW (1992) Brain maps: structure of the rat brain. Amsterdam: Elsevier Science Publishers.

Tanimura SM, Watts AG (1998) Corticosterone can facilitate as well as inhibit CRH gene expression in the rat hypothalamic paraventricular nucleus. Endocrinology 139:3830-3837.

Thiele TE, van Dijk G, Yagaloff KA, Fisher SL, Schwartz M, Burn P, Seeley RJ (1998) Central infusion of melanocortin agonist MTII in rats: assessment of c-Fos expression and taste aversion. Am J Physiol 274:R248-R254.

Watts AG (1992) Osmotic stimulation differentially affects cellular corticotropin releasing-hormone and neurotensin/neuromedin $\mathrm{N}$ mRNA levels in the lateral hypothalamic area and central nucleus of the amygdala. Brain Res 581:208-216.

Watts AG (1996) The impact of physiological stimulation on the expression of corticotropin-releasing hormone and other neuropeptide genes. Front Neuroendocrinol 17:281-326.

Watts AG (1999) Dehydration-associated anorexia: development and rapid reversal. Physiol Behav 65:871-878.

Watts AG, Sanchez-Watts G (1995a) A cell-specific role for the adrenal gland in regulating CRH mRNA levels in rat hypothalamic neurosecretory neurones after cellular dehydration. Brain Res 687:63-70.

Watts AG, Sanchez-Watts G (1995b) Physiological regulation of peptide messenger RNA colocalization in rat hypothalamic paraventricular medial parvicellular neurons. J Comp Neurol 352:501-514.

Watts AG, Sanchez-Watts G (1998) Hunger- and anorexia-associated patterns of neuropeptide gene expression in the rat hypothalamus. Soc Neurosci Abstr 24:449.

Watts AG, Kelly AB, Sanchez-Watts G (1995) Neuropeptides and thirst: the temporal response of corticotropin-releasing hormone and neurotensin/neuromedin $\mathrm{N}$ gene expression in rat limbic forebrain neurons to drinking hypertonic saline. Behav Neurosci 109:1146-1157.

Watts AG, Sanchez-Watts G, Kelly AB, Zheng JQ, Kay-Nishiyama C (1998) CRH in the lateral hypothalamic area, paraventricular, and parabrachial nuclei: a potential integrative network for generating anorexia. Physiologist 41:371.

Winn P (1995) The lateral hypothalamus and motivated behavior: an old syndrome reassessed and a new perspective gained. Curr Dir Psychol Sci 4:182-187.

Woods SC, Seeley RJ, Porte Jr D, Schwartz MW (1998) Signals that regulate food intake and energy homeostasis. Science 280:1378-1383. 